\title{
Catatan Penelitian
}

\section{Mutu Kimia dan Organoleptik Ubi Jalar Putih (Ipomoea Batatas) yang Difermentasi dalam Waktu yang Berbeda}

\section{The Quality of Chemical and Organoleptic Sweet Potato White (Ipomoea Batatas) Fermented In Different} Times

Dina Azalea Handayani*, Bambang Dwiloka, dan Nurwantoro

Program Studi Teknologi Pangan, Fakultas Peternakan dan Pertanian, Universitas Diponegoro, Semarang

*Korespondensi dengan penulis (dinazaleahandayani@yahoo.com)

Artikel ini dikirim pada tanggal 24 Mei 2016 dan dinyatakan diterima tanggal 4 Agustus 2016. Artikel ini juga dipublikasi secara online melalui www.jatp.ift.or.id. Hak cipta dilindungi undang-undang. Dilarang diperbanyak untuk tujuan komersial.

Diproduksi oleh Indonesian Food Technologists® @2017

\begin{abstract}
Abstrak
Penelitian ini bertujuan untuk mengetahui perbedaan mutu kimia dan mutu organoleptik ubi jalar putih (Ipomoea batatas) yang difermentasi dengan waktu yang berbeda. Parameter pengujian yang digunakan pada mutu kimia meliputi total padatan terlarut, kadar alkohol, $\mathrm{pH}$, dan mutu organoleptik seperti rasa, tekstur, dan tingkat kesukaan dengan lama fermentasi yang berbeda, sebagai perlakuan T1, T2 dan T3 yaitu 24 jam, 48 jam dan 72 jam. Rancangan Acak Lengkap dengan tujuh kali pengulangan digunakan dalam penelitian ini. Data yang diperoleh dianalisis dengan menggunakan ANOVA untuk parameter mutu kimia, sedangkan mutu organoleptic diuji dengan Kruskal Wallis. Hasil penelitian menunjukkan bahwa lama fermentasi berpengaruh nyata $(p<0,05)$ terhadap total padatan terlarut (TPT) dan kadar alkohol. Nilai pH tidak dipengaruhi $(p>0,05)$ oleh lama fermentasi. TPT tertinggi pada lama fermentasi 48 jam, kadar alkohol tertinggi pada lama fermentasi 72 jam, dan nilai pH terendah pada lama lama fermentasi 72 jam. Hasil uji organoleptik, lama fermentasi berpengaruh nyata $(p<0,05)$ pada rasa manis, asam, tekstur dan kesukaan. Rasa manis tertinggi pada lama fermentasi 24 jam, rasa asam tertinggi pada lama fermentasi 72 jam, tekstur terlunak pada 72 jam dan tingkat kesukaan panelis lebih menyukai tape dengan lama fermentasi 24 jam. Semakin lama fermentasi maka meningkatkan TPT, meningkatkan kadar alkohol, menurunkan nilai pH, menurunkan rasa manis, meningkatkan rasa asam, melunakkan tekstur dan menurunkan tingkat kesukaan.
\end{abstract}

Kata Kunci : ubi jalar putih, lama fermentasi, mutu kimia, mutu organoleptik

\begin{abstract}
This study attempts to knows the difference the quality of chemical and the quality of organoleptic sweet potato white (Ipomoea batatas) with fermentation in various duration of time. The quality of chemical, i.e. dissolved total solids, alcohol content, $\mathrm{pH}$, and the quality of organoleptic, i.e. taste, texture, and preferences after treatment T1, T2 and T3 (i.e. 24 hours, 48 hours and 72 hours, respectively). Completely Randomized Design with 7 times repetition was used in this research. The data were analyzed using ANOVA and Kruskal Wallis. The results indicated that length of fermentation provided significant impact $(p<0.05)$ to the dissolved total solids and alcohol content. $p H$ values was not influenced $(p>0.05)$ by the length of fermentation. The highest dissolved total solids was achieved by fermentation for 48 hours. Highest alcohol content was reached by 72 hours fermentation, and the lowest $\mathrm{pH}$ was on 72 hours. Based on organoleptic test results, the length of fermentation provided significant impact $(p<0.05)$ in a sweetness, sourness, texture and preferences. A sweetness was reached highly in fermentation for 24 hours, while a the most sour taste was on fermentation for 72 hours. Mushy texture was reached maximally in 72 hours and the most preferred tape could be reached by 24 hours fermentation.
\end{abstract}

Keyword: sweet potato white, long fermentation, the quality of chemical, the quality of organoleptic

\section{Pendahuluan}

Tape merupakan produk makanan tradisional Indonesia yang berbahan dasar mengandung karbohidrat yang tinggi serta melalui proses fermentasi dengan hasil produk yang memiliki citarasa manis hingga asam dengan sedikit flavor alkohol. Ada berbagai macam nama tape yaitu peyeum, tapai tela, tapai pulut, dan lain-lain. Indonesia memiliki berbagai sumber bahan pangan yang mengandung karbohidrat seperti singkong, beras ketan, dan ada juga ubi jalar. Jenis tape yang umum dikenal adalah tape singkong dan tape ketan. Pembuatan tape tidak hanya berbahan baku singkong maupun beras ketan, tetapi tape juga dapat dibuat dari ubi jalar karena kandungan karbohidrat ubi jalar relatif tingi.

Ubi jalar putih merupakan jenis ubi jalar yang memiliki warna daging umbinya putih dengan daging umbi lebih keras dan rasanya manis. Bentuk umbinya sendiri yaitu bulat dengan permukaan kulitnya tidak rata. Ubi jalar putih juga memiliki aroma, rasa dan sifat-sifat yang baik untuk diolah atau dimasak. Kandungan gizi setiap $100 \mathrm{~g}$ ubi jalar putih mengandung 123 kalori, protein $1,8 \mathrm{~g}$, lemak $0,7 \mathrm{~g}$, karbohidrat $27,9 \mathrm{~g}$ dan air 68,5 $\mathrm{g}$ (DKBM, 2005). Karena kandungan karbohidrat ubi jalar putih yang tinggi, kebanyakan masyarakat Indonesia biasa memanfaatkan ubi jalar ini menjadi produk seperti tepung tetapi ubi jalar juga dapat difermentasi. Sesuai dengan pendapat Susanto dan Saneto (1994) bahwa proses fermentasi merupakan salah satu alternatif yang baik dalam memanfaatkan ubi jalar, dan diharapkan masyarakat tidak bergantung pada singkong atau beras ketan sebagai bahan baku pembuatan tape. 
Proses fermentasi bahan pangan dapat berlangsung oleh adanya aktivitas beberapa jenis mikroorganisme seperti bakteri, khamir dan kapang. Mikroorganisme yang paling penting yaitu bakteri pembentuk asam laktat, bakteri pembentuk asam asetat dan beberapa jenis khamir penghasil alkohol. Pada proses fermentasi tape tidak diharapkan adanya udara sehingga harus dilakukan dalam kondisi anaerob. Menurut Fardiaz (1992) fermentasi merupakan proses pemecahan karbohidrat dan asam amino secara anaerobik, yaitu tanpa memerlukan oksigen. Proses fermentasi tape akan terjadi perombakan gula menjadi alkohol atau etanol, asam asetat, asam laktat, dan aldehid (Amerine et al., 1972). Starter yang digunakan pada proses fermentasi tape, menggunakan bantuan bahan starter ragi tape. Ragi tape merupakan kultur starter kering yang terbuat dari campuran tepung beras, ramuan bumbu, air dan ekstrak gula tebu (Merican dan Queeland, 2004). Ragi tape merupakan populasi campuran yang tediri dari spesies-spesies genus Aspergillus yang dapat memecah pati menjadi glukosa dan Saccharomyces, Candida, Hansenulla yang dapat menguraikan gula menjadi alkohol serta bakteri Acetobacter yang dapat merombak alkohol menjadi asam. Proses fermentasi pada tape biasanya membutuhkan waktu 45 jam dengan menggunakan suhu ruang $28-30^{\circ} \mathrm{C}$.

Penelitian ini pada dasarnya difokuskan untuk mengembangkan teori-teori yang ada dengan melihat kandungan karbohidrat dari ubi jalar putih. Tujuan dari penelitian ini adalah untuk mengetahui perbedaan mutu kimia ubi jalar yang difermentasi seperti total padatan terlarut (TPT), kadar alkohol, pH dan organoleptik seperti rasa (manis dan asam), tekstur dan kesukaan pada panelis dengan lama fermentasi yang berbeda.

\section{Materi dan Metode}

Materi

Bahan yang digunakan untuk pembuatan tape berbahan dasar ubi jalar adalah ubi jalar putih $\pm 5 \mathrm{~kg}$, ragi tape Na Kok Liong (NKL) 1 bungkus, daun pisang dan aquades. Peralatan yang digunakan untuk pengolahan dan analisa laboratorium meliputi alat-alat pengukus, baskom, panci, kompor, pisau, besek, $\mathrm{pH}$ meter, piknometer $50 \mathrm{ml}$, erlemeyer, labu Kjedahl, refraktometer, alat destilasi dan timbangan analitik.

Pengujian yang dilakukan untuk mengetahui mutu kima dari tape ubi jalar putih meliputi total padatan terlarut (TPT), kadar alkohol dan nilai derajat keasaman $(\mathrm{pH})$. Sedangkan pada uji organoleptik rasa manis maupun asam, tekstur dan kesukaan.

\section{Metode}

Penelitian mutu kimia dan organoleptik ubi jalar putih yang difermentasi dalam waktu yang berbeda dilaksanakan di Laboratorium Kimia dan Gizi Pangan, Program Studi Teknologi Pangan, Jurusan Pertanian, Fakultas Peternakan dan Pertanian, Universitas Diponegoro, Semarang.

Penelitian ini menggunakan 3 macam perlakuan yaitu T1 (lama fermentasi 24 jam), T2 (lama fermentasi
48 jam), dan T3 (lama fermentasi 72 jam). Penelitian meliputi proses pembuatan tape ubi jalar putih, analisa mutu kimia seperti total padatan terlarut (TPT) dengan metode refraktometer, kadar alkohol dengan metode destilasi, dan nilai derajat keasaman $(\mathrm{pH})$. Sedangkan pada analisa mutu organoleptik rasa manis, asam, tekstur, dan kesukaan menggunakan kuesioner dari 25 panelis agak terlatih. Rasa manis dibedakan dengan model skoring; skor 1 (tidak manis), 2 (agak manis), 3 (manis), 4 (sangat manis), sedangkan untuk rasa asam; skor 1 (tidak asam), skor 2 (agak asam), 3 (asam), 4 (sangat asam). Kategori skor tekstur; skor 1 (tidak lunak), 2 (agak lunak), 3 (lunak), 4 (sangat lunak) dan untuk skor kesukaan; skor 1 (tidak suka), 2 (agak suka), 3 (suka), 4 (sangat suka).

\section{Pembuatan Tape Ubi Jalar Putih}

Bahan utama untuk satu unit percobaan menggunakan ubi jalar putih dengan berat ubi di perkirakan $\pm 200 \mathrm{~g}$ dicuci bersih. Ubi jalar dikukus selama 30 menit sampai matang. Kemudian, dikeluarkan dari tempat pengukus dan didinginkan di atas nampan lalu dikupas kulitnya. Ubi jalar putih ditaburi ragi sebanyak $0,5 \%$ dari berat ubi jalar putih tersebut. Selanjutnya adalah pembungkusan dengan daun pisang dan penyimpanan dalam besek pada suhu ruang selama 24 jam, 48 jam dan 72 jam (T1, T2, dan T3).

\section{Analisis Statistik}

Data hasil uji mutu kimia dianalisis dengan analysis of varian (ANOVA) pada taraf signifikansi $5 \%$. Apabila terdapat signifikansi hasil maka dilanjutkan dengan Duncan. Hasil uji mutu organoleptik diuji terlebih dahulu dihitung normalitasnya dengan menggunakan uji non parametrik yaitu Kruskal Wallis dengan taraf signifikansi $5 \%$, apabila terdapat signifikansi hasil maka di lanjutkan dengan uji Mann-Whitney $U$. Semua data diolah dengan menggunakan program SPSS 16.0 for Windows.

\section{Hasil dan Pembahasan \\ Total Padatan Terlarut (TPT) \\ Berdasarkan hasil analisa pada uji total padatan} terlarut (TPT) dari fermentasi ubi jalar putih dengan waktu yang berbeda yaitu 24 jam, 48 jam dan 72 jam didapatkan hasil masing-masing sebesar $\mathrm{T} 1$ $\left(28,42^{\circ}\right.$ Brix); $\quad$ T2 $\left(30,00^{\circ}\right.$ Brix $) ; \quad$ T3 $\left(29,42^{\circ}\right.$ Brix $)$. Berdasarkan hasil dari Tabel 1, pengaruh lama waktu fermentasi terhadap total padatan terlarut memiliki perbedaan nyata $(p<0,05)$.

Hasil uji total padatan terlarut pada fermentasi ubi jalar putih ini terlihat bahwa pada lama fermentasi 48 jam memiliki nilai yang paling tinggi. Selama fermentasi, enzim dari bakteri merombak pati menjadi glukosa sehingga jumlah gula yang terbentuk tinggi. Total padatan terlarut yang terbentuk dari hasil fermentasi ubi jalar putih ini diduga merupakan campuran komponen seperti dekstrin, maltosa dan glukosa dalam ubi jalar yang larut ke dalam air. Kemungkinan juga rasa manis yang dimiliki ubi jalar sebelum difermentasi juga mempengaruhi jumlah TPT. Sesuai dengan pernyataan 
Tabel 1. Total Padatan Terlarut, Kadar Alkohol, dan Nilai pH dari Hasil Fermentasi Ubi Jalar Putih dengan Waktu yang Berbeda.

\begin{tabular}{cccc}
\hline Perlakuan & Variabel \\
\hline & $\begin{array}{c}\text { Total Padatan Terlarut } \\
\left.\text { ( }{ }^{\circ} \text { Brix }\right)\end{array}$ & Kadar Alkohol (\%) & Nilai pH \\
\hline T1 & $28,42 \pm 0,97^{\mathrm{a}}$ & $2,17 \pm 1,68^{\mathrm{a}}$ & $4,95 \pm 0,73^{\mathrm{a}}$ \\
T2 & $30,00 \pm 1,00^{\mathrm{b}}$ & $2,58 \pm 1,94^{\mathrm{a}}$ & $5,00 \pm 0,27^{\mathrm{a}}$ \\
T3 & $29,42 \pm 0,97^{\mathrm{ab}}$ & $7,06 \pm 2,68^{\mathrm{b}}$ & $4,75 \pm 0,32^{\mathrm{a}}$ \\
\hline
\end{tabular}

Keterangan: superskrip berbeda pada kolom yang sama menunjukkan perbedaan nyata $(p<0,05)$

Tabel 2. Rata-Rata Organoleptik Hasil Fermentasi Ubi Jalar Putih dengan Waktu yang Berbeda

$\begin{array}{ccccc}\text { Perlakuan } & \text { Skor Rasa Manis } & \text { Skor Rasa Asam } & \text { Skor Tekstur } & \text { Skor Kesukaan } \\ \text { T1 } & 2,28 \pm 0,80^{\mathrm{a}} & 2,25 \pm 0,79^{\mathrm{a}} & 2,20 \pm 0,83^{\mathrm{a}} & 2,28 \pm 0,77^{\mathrm{a}} \\ \text { T2 } & 1,72 \pm 0,65^{\mathrm{b}} & 2,71 \pm 0,87^{\mathrm{ab}} & 2,77 \pm 0,76^{\mathrm{b}} & 1,54 \pm 0,46^{\mathrm{a}} \\ \text { T3 } & 1,66 \pm 0,67^{\mathrm{b}} & 2,94 \pm 0,68^{\mathrm{b}} & 2,85 \pm 0,88^{\mathrm{b}} & 1,81 \pm 0,73^{\mathrm{ab}}\end{array}$

Keterangan: superskrip berbeda pada kolom yang sama menunjukkan perbedaan nyata $(p<0,05)$

Narullita et al. (2013) bahwa total padatan terlarut merupakan seluruh komponen bahan padatan yang ada dan larut dalam air di dalam umbi termasuk gula reduksi, sukrosa, asam organik serta vitamin yang larut dalam air.

\section{Kadar Alkohol}

Pengujian kadar alkohol hasil fermentasi ubi jalar putih dengan waktu yang berbeda yaitu 24 jam, 48 jam dan 72 jam menghasilkan kadar alkohol masing-masing sebesar T1 (2,17\%); T2 (2,58\%); T3 (7,06\%). Berdasarkan hasil dari Tabel 1, pengaruh kadar alkohol dengan lama waktu fermentasi memiliki perbedaan nyata $(p<0,05)$.

Peningkatan jumlah kadar alkohol terhadap lama fermentasi ini adalah karena semakin tinggi jumlah kadar alkohol yang terbentuk. Sesuai dengan pernyataan Hasanah et al. (2012), terdapat pengaruh antara lama fermentasi terhadap jumlah kadar alkohol pada suatu produk. Pada fermentasi 24 jam, alkohol yang dihasilkan masih sedikit, hal ini dikarenakan bakteri Saccharomyces cerevisiae yang ada dalam bahan masih dalam tahap adaptasi dan belum ada pertumbuhan. Pada fermentasi 48 jam mangalami sedikit peningkatan alkohol dari yang sebelumnya. Hal ini disebabkan sudah terjadinya perombakan antara karbohidrat menjadi glukosa, maka pada fermentasi ke72 jam alkohol yang dihasilkan semakin meningkat karena glukosa yang telah dihasilkan, akan dirombak menjadi alkohol. Asngad dan Suparti (2009) menjelaskan bahwa semakin lama waktu proses fermentasi maka Saccharomyces cerevisiae akan bekerja secara optimal merombak glukosa, sukrosa dan maltosa sehingga mampu menghasilkan alkohol dengan konsentrasi tinggi.

\section{Derajat Keasaman $(\mathrm{pH})$}

Berdasarkan hasil analisa uji nilai $\mathrm{pH}$ hasil fermentasi ubi jalar putih dengan waktu yang berbeda yaitu 24 jam, 48 jam dan 72 jam, didapatkan nilai $\mathrm{pH}$ masing-masing sebesar T1 $(4,95)$; T2 $(5,00)$; T3 $(4,75)$. Berdasarkan hasil dari Tabel 1, terlihat tidak ada pengaruh lama waktu fermentasi terhadap nilai $\mathrm{pH}$ karena tidak memiliki perbedaan nyata $(p>0,05)$. Tidak adanya pengaruh lama fermentasi terhadap nilai $\mathrm{pH}$ ini dapat disebabkan karena kurangnya lama waktu fermentasi. Terdapat penurunan nilai $\mathrm{pH}$ pada fermentasi 72 jam mengalami penurunan nilai $\mathrm{pH}$ dari yang sebelumnya yaitu 48 jam. Hal ini sesuai dengan pendapat Adhitya et al. (2012) bahwa semakin lama waktu fermentasi maka kadar keasaman semakin tinggi sehingga nilai $\mathrm{pH}$ yang dihasilkan semakin menurun.

Rasa

Uji organoleptik penilaian rasa yang digunakan yaitu rasa manis dan asam. Berdasarkan hasil penelitian yang telah dilakukan pada uji organoleptik untuk rasa manis pada hasil fermentasi ubi jalar putih dengan waktu yang berbeda yaitu 24 jam, 48 jam dan 72 jam, masingmasing didapatkan nilai sebesar T1 $(2,28)$; T2 $(1,72)$; T3 $(1,66)$ sedangkan untuk rasa asam masing-masing adalah T1 (2,25); T2 (2,71); T3 (2,94). Tabel 2 menunjukkan adanya perbedaan nyata terhadap lama fermentasi dengan rasa manis dan rasa asam yang terbentuk $(p<0,05)$.

Dapat dilihat dari hasil tersebut bahwa rasa manis memiliki kriteria rasa dari tidak manis sampai agak manis, skor tertinggi didapatkan pada fermentasi 24 jam. Sedangkan kriteria untuk rasa asam yaitu dari agak asam sampai asam dengan skor tertinggi diperoleh pada fermentasi 72 jam. Hasil dari rasa manis dan asam ini berbanding terbalik. Rasa agak manis yang dimiliki tape ubi jalar putih pada fermentasi 24 jam disebabkan selama fermentasi tidak ada penambahan bahan gula pasir dan rasa yang terbentuk ini dikarenakan rasa manis yang timbul dari ubi jalar itu sendiri serta belum sempurnanya proses fermentasi. Menurut Santosa dan Prakosa (2010) prinsip dasar dari fermentasi pangan yang mengandung pati adalah perombakan komponen dari pati menjadi dekstrin dan gula selanjutnya menjadi alkohol sehingga menghasilkan rasa manis sedikit alkoholik.

Sedangkan untuk rasa asam yang dimiliki pada fermentasi 72 jam ini dipengaruhi karena lamanya proses fermentasi, semakin lama proses fermentasi maka semakin tinggi rasa asam yang terbentuk. Menurut pendapat Unika (2015) semakin lama proses fermentasi maka semakin banyak pula mikroorganisme yang merombak pati menjadi glukosa hingga menjadi alkohol maka kadar alkohol yang semakin tinggi membuat tape menjadi asam. 
Tekstur

Tekstur pada hasil fermentasi suatu bahan makanan sangat penting dilakukan untuk membedakan tekstur awal sampel dengan tekstur yang dihasilkan setelah fermentasi dengan menggunakan indera perabaan. Pada uji organoleptik untuk tekstur pada hasil fermentasi ubi jalar putih dengan waktu yang berbeda yaitu 24 jam, 48 jam dan 72 jam, didapatkan nilai sebesar T1 $(2,20) ;$ T2 $(2,77) ;$ T3 $(2,85)$. Tabel 2 menunjukkan adanya perbedaan nyata terhadap lama fermentasi dengan tekstur yang terbentuk $(p<0,05)$.

Tekstur pada hasil fermentasi ubi jalar putih ini memiliki hasil kriteria dari agak lunak sampai lunak. Lama fermentasi 72 jam memberikan hasil organoleptik tekstur yang lebih lunak dibandingkan fermentasi 24 jam dan 48 jam. Adanya perbedaan lama waktu fermentasi dapat memberikan pengaruh yang nyata pada tekstur dari hasil suatu produk yang difermentasi. Hal ini sependapat dengan Fahmi dan Nurrahman (2011) bahwa semakin lama fermentasi maka akan menghasilkan tekstur yang lebih lunak dan berair dikarenakan proses fermentasi secara anaerob yang menghasilkan air $\left(\mathrm{H}_{2} \mathrm{O}\right)$.

\section{Kesukaan}

Kesukaan merupakan keseluruhan tanggapan panelis mengenai beberapa parameter seperti rasa, aroma, tekstur dan warna. Hasil uji organoleptik untuk kesukaan pada hasil fermentasi ubi jalar putih dengan waktu yang berbeda yaitu 24 jam, 48 jam dan 72 jam didapatkan nilai masing-masing sebesar T1 $(2,28)$; T2 $(1,54)$; T3 $(1,81)$. Tabel 2 menunjukkan adanya perbedaan nyata terhadap lama fermentasi dengan kesukaan panelis yang dihasilkan $(p<0,05)$.

Lamanya waktu fermentasi yang dilakukan dapat mengubah rasa dan tekstur dari tape ubi jalar putih. Menurut hasil kriteria kesukaan, didapat hasil tidak suka sampai agak suka. Rata-rata panelis memilih hasil fermentasi ubi jalar dengan lama waktu fermentasi 24 jam dikarenakan rasanya yang agak manis dan teksturnya agak lunak dibandingkan dengan lama fermentasi 48 jam dan 72 jam yang rasanya lebih ke asam. Menurut Unika (2015) kesukaan panelis pada tape yang umumnya didapat karena tape memiliki rasa manis karena mengandung gula dan sedikit mengandung alkohol.

\section{Kesimpulan}

Semakin lama waktu fermentasi ubi jalar putih maka dapat meningkatkan total padatan terlarut, meningkatkan jumlah kadar alkohol, menurunkan nilai $\mathrm{pH}$, menurunkan rasa manis, meningkatkan rasa asam, melunakkan tekstur dan menurunkan tingkat kesukaan pada panelis. Berdasarkan hasil penelitian, maka sebaiknya dilakukan lama fermentasi 24 jam untuk memenuhi kesukaan panelis yang agak manis, tidak terlalu lunak dan sedikit mengandung alkohol.

\section{Daftar Pustaka}

Adhitya, S.G., Yusa, N.M., Yusasrini, N.L.A.. 2012. Pengaruh waktu pengukusan dan fermentasi terhadap karakteristik tape ubi jalar ungu (Ipomoea batatas var. Ayamurasaki). J. Ilmu dan Tek. Pangan. 1(1): 1-9.

Amerine, M., Berg, A., Croes, M.V. 1972. The Technology of Wine Making, The AVI Publishing Company, Wesport, Connecticut.

Asngad, A., Suparti. 2009. Lama fermentasi dan dosis ragi yang berbeda pada fermentasi gaplek ketela pohon (Manihot utilissima Pohl) varietas mukibat terhadap kadar glukosa dan bioetanol. J. Penelitian Sains dan Teknologi. 10(1): 1-9.

Daftar Komposisi Bahan Makanan (DKBM). 2005. Depkes RI. Jakarta.

Fahmi, N., Nurrahman. 2011. Kadar glukosa, alkohol dan citarasa tape onggok berdasarkan lama fermentasi. J. Pangan dan Gizi. 2(3): 25-42.

Fardiaz, S. 1992. Fisiologi Fermentasi. Bogor: Pusat antar Universitas Institut Pertanian Bogor.

Hasanah, H., A. Jannah dan A. G. Fasya. 2012. Pengaruh lama fermentasi terhadap kadar alkohol tape singkong (Manihot utilissima Pohl). J. Alchemy. 1(2): 68-79.

Merican Z, Queeland, Y. 2004. Tape Processing In Malaysia: A Technology In Transition. Industrialization of Indigeneous Fermented Foods, pp. 247-270. Marcel Dekker Inc., New York.

Narullita, A., Waluyo, S., Novita, D.D. 2013. Sifat fisik ubi jalar (ubi jalar gisting Kabupaten Tanggamus dan jati agung Kabupaten Lampung Selatan) pada dua metode penyimpanan. J. Teknik Pertanian. 2(3): 133-146.

Santosa, A., Prakosa, C. 2010. Karakteristik tape buah sukun hasil fermentasi penggunaan konsentrasi ragi yang berbeda. J. Magistra. 22(73): 48-55.

Susanto, T., Saneto. 1994. Teknologi Pengolahan Hasil Pertanian. Bina Ilmu, Surabaya.

Unika, A. 2015. Pengaruh jumlah ragi dan waktu fermentasi terhadap sifat organoleptik tapai pisang tanduk. E-Journal Boga. 4(1): 192-201. 